\title{
Public Programming for Academic Libraries?
}

\author{
Sylvia C. Krausse \\ University of Rhode Island
}

Academic libraries, unlike their public counterparts, generally present few special extracurricular programs designed to draw in more patrons, expand the horizons of present patrons, and improve community relations. ${ }^{1}$ Why is this so? Some of the reasons may be the demands of a special clientele: faculty and students; the academic expectations of the librarians themselves necessary to serve in-depth subject areas; or library management which must balance campus concerns and fiscal responsibility to college or university administrations. State-supported institutions, however, often advertise their services to taxpayers as partial support for budgetary requests and pride themselves on faculty contributions to community activities. However, producing an innovative library program to serve both academic and public clienteles can result in frustration, complications and discouragement.

In this article, I will describe my experiences in working to "float" a special program at the University of Rhode Island ${ }^{2}$ (URI) Library, where I am a reference/interlibrary loan librarian and bibliographer. It is my hope that others who may attempt such projects in the future will thus gain insights into what to expect-and some pitfalls to avoid.

With the general trend toward more efficient use of resources, academic libraries with their vast stores of information and numerous experts in many fields are possibly being wasted if they do not come to the forefront of program planning. And especially in relatively isolated locations like Kingston, where the University is virtually the "only game in town," the need for programs both to serve the community and to challenge the library faculty is probably greater than average. Thus, statewide (since the University is the state's major public academic collection) and local considerations suggest that programs might be both welcomed by the Rhode Island public and able to tap some of the abundant resources available throughout the state.

My involvement with programming began in December 1981, when I saw a notice in College b Research Libraries News about the availability of

${ }^{1}$ C. Poucher, "Innovations in Program Planning in Academic Libraries," $R Q 18$ (Spring 1979):264-66.

${ }^{2}$ The University of Rhode Island is the State University, located in the southern part of Rhode Island in the village of Kingston. The University is of medium size and enrolls about 13,000 undergraduates and 2,500 graduates and has a full-time faculty of over 800 . grants for workshops and assistance for public programming in the humanities for academic libraries, sponsored by the Association of College \& Research Libraries (ACRL) and the National Endowment for the Humanities (NEH). I was delighted that monies had become available in my area of interest and applied immediately. My humanist teammate was Natalie Kampen, associate professor of art history. The URI team was accepted for the workshop in Los Gatos, California, on February 23-25, 1982. Each participant received a maximum expense grant of $\$ 150$ from the $\mathrm{NEH}$, and the URI team also applied for and received additional travel money from their respective colleges. For a description of the workshop, see CむRL News, May 1982, pp.169-72.

At the workshop we considered the resources of the University and the State and with the help of the workshop leaders we decided to concentrate on Islamic arts, mainly because of Professor Kampen's involvement with the Islamic "culture cluster." (A program of foreign culture clusters has been designed by the College of Arts \& Sciences to meet undergraduate division requirements and to introduce students via two or more courses in a foreign culture to such humanities areas as the Islamic World, France, or Russia.) Combining this interest with current news on Islam in the Middle East, we wanted to make the Rhode Island community aware of the diversity of Islam-after all, Islamic culture and religion stretches from southern $\mathrm{Eu}$ rope across the Asian continent to Indonesia and the Philippines.

Immediately upon returning from the workshop we set the wheels in motion to apply for a grant and soon realized that because of time constraints and many uncertain factors it was best to apply for a planning grant first. We enlisted the help of a history professor, Richard Roughton, who is an Islamic expert. As suggested by the NEH workshop leaders our first task was to design a committee of consultants. We invited librarians, humanists and curators from the University of Rhode Island, the Museum of Art of the Rhode Island School of Design, Rhode Island College, and the Textile Museum in Washington, D.C., as well as various Muslim members from the Rhode Island community to make up the committee.

Textiles, rugs and other handicrafts of the Muslim world were chosen to attract public interest and curiosity and to teach Rhode Islanders to appreciate an unfamiliar culture. The program was designed to consist of several related parts: displays, lectures and films. Ideally, two exhibits were planned, one to be shown at the URI Library and the other in Providence. Both were to be opened by well-known Islamic experts and 
throughout the programming period films and additional talks were scheduled in Kingston as well as in Providence.

However, complications soon appeared.

Security of valuable items was absolutely essential. Exhibition space in the URI Library is available in the form of a few glass cases only, providing no security whatsoever.

Temperature control was another important consideration; without the guarantee of proper temperature control and tight security no institution would ever allow their artifacts to be displayed at another institution. Therefore, the major exhibit had to be scheduled at the URI Fine Arts Center and a smaller and less costly showing at the URI Library was consequently added to the program.

Long term scheduling was necessary for the contributors but impossible to manage on the tentative basis of a grant proposal.

Time for coordination, writing and making the arrangements was considerable. This was difficult for all the planners and consultants and I could not, however, obtain a guarantee from the URI Library that if the project were funded I would even get release time to carry the program to completion. It became clearer as the preliminary planning advanced that even if the planning grant were approved, the situation could easily get out of hand.

Release time difficulties, remuneration problems, lack of real support from my department and the slowness of the University and state bureaucra- cies to move and to react to the inevitable alterations in long-range planning (in such areas as scheduling and disbursement of funds, for example) could create impossible log-jams in the few months between funding approval and the program opening. Thus, though it pains me to say so, I must admit when the planning grant was rejected, I was relieved.

In retrospect, I realized why so few academic libraries have done this sort of public programming: the obstacles inherent in the university system can be simply overwhelming in light of all the paperwork and preparations involved with obtaining funding even at the planning stages. In my experience, participants spent considerable amounts of their own time and money during the lengthy and involved process of roughing out the program and preparing a formal grant application. Faculty consultants within the University have to be convinced to add to their workloads with no added monetary compensation, and the "catch-22" of uncertainty of release time (made even more uncertain by the staff shortages prevalent nowadays) must be faced. And, of course, bureaucratic inertia must be overcome or outmaneuvered.

I think a realistic approach to what one's involvement may entail could be helpful and I hope my experiences will serve as an example of some of the problems which, if unavoidable, can at least be identified in advance and accommodated.

\section{ACRL 1983/84 Budget}

At its June 1983 meeting, the ACRL Board approved the 1983/84 budget. Highlights for the budget year include:

-the extension of the Bibliographic Liaison Project for another year;

- the purchase of a terminal with a view to ACRL participation in the ALANET electronic mail and database program;

- the continuation of the ACRL Jobline, Fast Job Listing Service, and ACRL 100 Libraries Project;

-increased levels of support for ACRL committees, chapters, and sections;

-the Third ACRL National Conference in Seattle;

- a preconference for the Rare Books and Manuscripts Section to be held in Austin, Texas;

- a balanced budget for the Continuing Education program;

-ACRL staff support for the J. Morris Jones leadership project award;

-a $\$ 3,000$ subsidy to ALA Publishing to underwrite the publication costs of the next Publication in Librarianship Series monograph;

- support for newsletters for the Bibliographic
Instruction Section, the Rare Books and Manuscripts Section, and the Western European Specialists Section;

- a budget for Choice which exceeds $\$ 1$ million for the first time;

- the transfer of advertising activities for $C \mho R L$ and $C \& R L$ News to Choice with the expectation of increased revenues as a result;

- the offering of three NEH workshops in cooperation with the Public Libraries Association during the next year.

The 1982/83 fiscal year showed a strong performance by all ACRL programs, although the total continuing education program (revenues and expenses) was smaller than planned. Revenues were slightly under budget, but this was offset by significant savings achieved in expenses. ACRL added $\$ 42,500$ and Choice added $\$ 90,300$ to their respective fund balances.

The budget for 1983/84 is presented first in summary form and then in more detail, grouped by the four categories:

-membership dues and activities;

-publications; 